\title{
Çocuğu Hastanede Yatan Ebeveynlerin Aile Merkezli Bakım Alma Durumlarını Etkileyen Faktörlerin Belirlenmesi
}

\author{
Handan Boztepe ${ }^{1} \odot$, Gizem Kerimoğlu Yıldız² ${ }^{2}$, Sevil Çınar ${ }^{3} \odot$, Ayşe $A^{4}{ }^{4}$
}

1Atıım Üniversitesi, Sağlık Bilimleri

Fakültesi, Hemşirelik Bölümü, Ankara, Türkiye

${ }^{2}$ Mustafa Kemal Üniversitesi, Sağlık

Bilimleri Fakültesi, Hemşirelik

Bölümü, Çocuk Sağlığı ve Hastalıkları

Hemşireliği Anabilim Dalı, Hatay,

Türkiye

${ }^{3}$ Artvin Çoruh Üniversitesi, Sağlık

Bilimleri Fakültesi, Çocuk Sağlığı ve

Hastalıkları Hemşireliği Anabilim Dalı,

Artvin, Türkiye

${ }^{4}$ Hacettepe Üniversitesi, Hemşirelik

Fakültesi, Çocuk Sağlığı ve Hastalıkları Hemşireliği Anabilim Dalı, Ankara, Türkiye

Handan Boztepe, Dr. Öğr. Üyesi Gizem Kerimoğlu Yıldız, Arş. Gör. Dr. Sevil Çınar, Arş. Gör. Dr.

Ayşe Ay, Arş. Gör.

Illetişim:

Dr. Öğr. Üyesi Handan Boztepe Atılım Üniversitesi, Sağlık Bilimleri Fakültesi, Hemşirelik Bölümü, Ankara, Türkiye Tel: +903125866103

E-Posta:boztepehandan@gmail.com
ÖZET

Amaç: Bu araştırmanın amacı, çocuğu hastanede yatan ebeveynlerin, aile merkezli bakım uygulamalarına katılıma durumları ve etkileyen faktörleri belirlemektir.

Hastalar ve Yöntem: Bu kesitsel araştırma bir çocuk hastanesinin yataklı servislerinde çocuklarına refakat eden ebeveynler ile Temmuz 2014- Nisan 2015 tarihleri arasında gerçekleştirilmiştir. Araştırmanın örneklem grubunu araştırmaya katılmayı kabul eden 303 ebeveyn oluşturmuştur.

Bulgular: Ebeveynlerin çoğunluğunun (\%95) hastanede çocuklarının bakımına katıldıkları, en çok bakımına katıldıkları uygulamaların çocuğun temel fiziksel bakımını karşılamaya yönelik uygulamalar (yemek yeme, hijyen gereksinimlerini karşılama) ve ilaç uygulaması olduğu $(\% 37,6)$ belirlendi. Çocukları planlı bir şekilde hastaneye yatırılan ebeveynlerin sağılık profesyonellerine daha fazla soru sorabildiği belirlenmiştir $(p<0,05)$. Ebeveynlerin çoğunluğunun $(\% 72.6)$ teslimlere katılmak istedikleri belirlendi. Ebeveynlerin eğitim seviyeleri ve çocuklarının hastalığını, hastanede aldıkları tedavi protokolünü, çocuklarına yapılan uygulamaların nedenlerini ve yatak başı hemşire teslimlerini anlama durumları arasında istatistiksel olarak anlamlı bir fark olduğu bulundu $(p<0.05)$.

Sonuç: Bu araştırmanın sonucunda, çocukları hastanede yatan ebeveynlerin aile merkezli bakım sürecine katılmalarııı planlarken; ebeveynlerin eğitim seviyesi ve çocukların hastaneye yatış şekli gibi özelliklerin, sağlık profesyonelleri tarafından dikkate alınması gerekliliği sonucu ortaya çıkmıştı.

Anahtar sözcükler: Aile merkezli bakım, çocuk hemşireliği, ebeveyn katıımı

\section{DETERMINATION OF FACTORS AFFECTING THE STATUS OF HOSPITALIZED CHILD'S PARENT FOR RECEIVING} FAMILY-CENTERED CARE

\section{ABSTRACT}

Purpose: The aim of this study is to determine the participation of parents of hospitalized children in family-centered care implementation and factors that affect it.

Patients and Methods: This cross-sectional study was conducted on parents who accompanied their children in inpatient services in a children's hospital between July 2014 and April 2015. The sample group of the study consisted of 303 parents who agreed to participate in the study.

Results: It was determined that the majority of parents (95\%) were involved in the care of their children in the hospital, the practices they attended were mostly about children's basic physical care (feeding, hygienic requirements) and medication (37.6\%). It was determined that parents whose children hospitalized in a planned way had a chance to ask more questions to the health professionals $(p<0.05)$. It was determined that the majority of parents $(72.6 \%)$ wanted to participate in nursing bedside shift. There was a statistically significant difference $(p<0.05)$ between education levels of parents and the state of parents' knowledge about the disease of their children, the treatment protocol received by their children in the hospital, the reasons of implementations applied to their children, and their state of understanding the nursing bedside shift report.

Conclusion: As a result of this research, when we plan to include parents of hospitalized children in the family-centered care process, the characteristics such as the education level of parents and the way of hospitalizing children should be considered by health professionals.

Keywords: Family-centered care, pediatric nursing, parent participation 
A ile merkezli bakım, hastanede yatarak tedavi gören çocuğun bakımına ailenin katııımını destekleyen çocuk, aile ve sağlık personeli arasında sağlık bakımının planlanmasında, uygulanmasında ve değerlendirilmesinde ortak yarar sağlanmasını amaçlayan bir yaklaşımdır. Bu bakım yaklaşımında sağlık personelleri çocukların ve ailelerin içsel güçlerine ve kültürel değerlerine saygı duyar ve bakım ve karar verme rollerinde aileleri destekler ve güçlenmelerini sağlar (1). American Nurses Association (ANA), American Association of Critical-Care Nurse (AACNs), ve Society of Pediatric Nurses (SPN) gibi birçok hemşirelik örgütü de aile merkezli bakımı desteklemektedir (2). Çocuğun hastaneye yatması ebeveynlerin, çocuklarının primer bakım vericisi olma rolünü sağlık çalışanlarına devretmelerinden dolayı ebeveynlik rollerinden uzaklaşmalarına neden olabilmektedir (3). Ayrıca ebeveynler hastanede çocuklarının yanında olmak, onlara bakım vermek ve desteklemek istemektedirler (4). Ebeveynlerin hastanede yatan çocuğun bakımında aktif olarak rol alması ise aile merkezli bakım felsefesinin temel yapısını oluşturmaktadır $(5,6)$.

Aile merkezli bakım uygulamaları ile ebeveynler çocuklarının bakımına katılarak sağlık personeli ile aralarında güvene dayalı etkili iletişim kurabilirler, çocukları ile ilgili deneyimlerini paylaşabilirler ve çocuklarının durumu, hastalığın süreci ve tedavi ile ilgili bilgilere daha kolay ulaşabilirler (7, 8), Shelton ve Stepanek (9) çalışmalarında ebeveynler ve sağlık personelleri arasında her zaman, tam ve tarafsız bilgi alışverişini desteklemenin aile merkezli bakımın anahtar ögelerinden biri olduğunu belirtmişlerdir. Sağlık personeli ve ebeveynler arasındaki iletişim ve ulaşılabilirliğin sağlanamaması ebeveynlerin yetersiz bilgi almasına ve aile merkezli bakımın uygulanmasında bir engel oluşmasına yol açabilmektedir (10). Eğer bilgiler etkin bir şekilde paylaşılmazsa ebeveynler güven duygusunu kaybedebilir ve bu durum, ebeveynlerin bakıma katılmasını engelleyebilir, ebeveynlerin anksiyetelerinin artmasına, üzüntü ve yalnızlık duyguları yaşamalarına neden olabilmektedir (11). Şener ve Karaca (2017), annelerin hemşirelerden hastanede yatan çocukların bakımın katılmasını sağlama ve bakıma katılmaları için onlardan destek görme gibi beklentileri olduğunu bildirmiştir (12). Aile merkezli bakım hizmeti sağlanmadığında ebeveynlerin anksiyetesinin çocuğa yansımasına, çocuğun enerjisinin iyileşmekten çok stresle baş etmeye harcanmasına, iyileşme süresinin gecikmesine ve özellikle küçük yaş grubu çocukların anne-bebek bağlanmasının etkilenmesi, uyum problemleri gibi olumsuz psikososyal sorunların görülmesine yol açabilir $(13,14)$. Ayrıca Aykanat ve Gözen'in yaptıkları çalışmalarında (2014) yenidoğan yoğun bakım ünitesinde bebek bakımına katılımı desteklenmeyen annelerin bebeklerine bakım verme becerilerinin düşük olduğu ve bu bebeklerin yeterli bakım alamadıkları görülmüştür (15). Çakmak ve Karaçam (2018) ise annelerin yoğun bakım ünitesinde yatan bebeğin bakımına dahil edilmesiyle bebek bakım becerilerinin arttığını ifade etmiş̧tir (14).

Hastalık, tanı ve tedavi nedeniyle hastanede yatan çocuğun sıklıkla deneyimlediği ağrılı işlemler en çok deneyimlenen ve istenmeyen durumlardan biridir. Hastanede yatan çocuk için en travmatik deneyimlerden biri olan ağrılı ve invaziv işlemler sırasında çocuk ve ailenin birlikte olabilmeleri aile merkezli bakımın bir diğer önemli katkısıdır. Literatürde hem çocukların hem de ebeveynlerin işlemler sırasında çocuklarıyla birlikte olmak istedikleri de belirlenmiştir (5). Ancak sağlık personelinin konu ile ilgili tutumu mesleklere ve eğitim düzeylerine göre farklılık göstermektedir (8). Çocuğun travmatik işlemlere bağlı yaşadığı ağrısı ve anksiyetenin azaltılmasında ebeveynlerin çocuğun yanında olması önemlidir (16). Özçetin ve ark. (2011) yaptığı çalışmada intravenöz katater takılması sırasında ailesinin yanında bulunduğu 3-6 yaş grubu çocukların ağıı toleransının kontrol grubuna göre daha iyi olduğu bildirilmiștir (17). Aile merkezli bakım hastane ortamında ebeveynlerin ve çocukların bir arada olmasını sağlayarak çocuğun baş etmesine katkıda bulunmaktadır (18). Reijneveld ve ark. (2017) ise verilen aile merkezli bakım uygulamalarının bebeklerin sosyoemosyonel problemlerinin erken dönemde fark edilmesini ve 18. ayında daha az problem yaşamasına yol açtığını bildirmiştir (19). Çamur ve Karabudak (2017) ebeveyn katııımının çocuğun anksiyetesi üzerindeki etkisini değerlendirdiği çalışmasında ebeveynlerin çocuğun bakımına katııımının çocuğun anksiyetesini azalttığını bildirmiştir (20). Çocuğa duygusal destek sağlamada gerekli olan ebeveynler ile ilişkinin hastanede kalınan süre boyunca devamlılığı aile merkezli bakım ile gerçekleştirilebilir.

Literatürde de aile merkezli bakım kavramı "bakıma katılma", "ağrılı işleme/ CPR uygulamasına ebeveyn katılımı", "çocuk ve ailelerle iletişim" gibi başıklar altında ele alınmaktadır (3-8). Ancak son yıllarda literatürde aile merkezli bakım kavramı içerisinde ailelerin teslimlere katılımını ve aile merkezli vizitlerin de gündeme geldiği görülmetkedir $(21,22)$. Amerikan Pediatri Akademisi tarafından son yıllarda "aile merkezli teslimler" ve "ailenin teslimlere katılımının" önemi vurgulanmakta ve bu durum aile merkezli bakıma yeni bir boyut kazandırmaktadır (21). Aile merkezli teslimler "hasta ve ailesinin de tedavi planının kontrolünü paylaştığı interdisipliner teslimler" olarak tanımlanmıştır (22). Aile merkezli veya ailenin katılımı ile gerçekleştirilen teslimlerde hekim, hasta, hemşire ve ebeveyn de aktif olarak 
teslimlere katılmaktadır. Bu yaklaşımla ebeveynin ve çocuğun bakımından sorumlu sağlık ekibinin bilgi alışverişinde bulunması kolaylaşmakta ve ailelerin karar verme sürecine katılmaları desteklenmektedir (21). Konuyla ilgili yapılan çalışmalarda ailenin teslimlere katılmasının ebeveynler ve sağlık elemanları arasında iletişimi geliştirdiği, ailenin çocuğun hastalığını ve sürecini nasıl yönetebileceklerini daha iyi anlamalarını sağladığını göstermektedir $(6,7,23,24)$. Ayrıca yine çalışmalarda çocuğu hastaneye yatan ebeveynlerin çoğunun teslimlerde yer almak istediğini, mahremiyet kaybı ve rahatsı hissetme gibi potansiyel riskleri de kabul ettiklerini, bununla birlikte teslimler sırasında soru sorma fırsatı bulduklarını ve karar verme sürecine daha etkin katıldıklarını ifade ettikleri belirlenmiştir $(25,26)$. Ülkemizdeki literatür incelendiğinde aile merkezli bakımla ilgili çalışmaların olduğu bununla birlikte ailelerin hemşire teslimlerine katıımlarını inceleyen çalışmaların olmadığı belirlenmiştir. Bu çalışmanın amacı, çocuğu hastanede yatan ebeveynlerin, çocuğun hastanede yatışı süresince aile merkezli bakım alma, çocuğun bakımına katılma durumları ve etkileyen faktörleri belirlemektir. Bu araştırmanın verileri doğrultusunda ebeveynlerin çocuğun bakımına katılma durumları ve etkileyen faktörleri belirlenerek aile merkezli bakım uygulamalarının geliştirilmesinin ilk adımının gerçekleştirilmesi hedeflenmektedir. Bu araştırmadan elde edilen verilerin hastane yönetimi ile paylaşılması ve aile merkezli bakım uygulamalarının desteklenmesi planlanmaktadır.

\section{Araştırma soruları}

1. Ebeveynlerin çocuklarının bakımına, çocuklarına uygulanan ağrılı işlemlere ve hemşire teslimlerine katılım durumları nedir?

2. Ebeveynlerin hemşirelere soru sorma durumları nedir?

3. Ebeveynlerin aile merkezli bakım almalarını etkileyen faktörler nelerdir?

\section{Gerec ve yöntem}

\section{Evren ve örneklem}

Araştırmanın evrenini Ankara ili içerisinde bulunan bir üniversitenin çocuk hastanesinin yataklı servislerinde Temmuz 2014- Nisan 2015 tarihleri arasında çocuklarına refakat eden ebeveynler oluşturmuştur. Araştırmaya bu üniversite hastanesinin yataklı servislerinde (bir çocuk yoğun bakım ünitesi, bir çocuk cerrahi ünitesi, bir çocuk dahiliye servisi ve bir yenidoğan servisi) araştırma kriterlerine uyan ve Temmuz 2014-Nisan 2015 tarihleri arasında belirtilen yataklı servislerde bulunan ve çocuklarına refakat eden 303 ebeveynler dahil edilmiştir. Bu servislerin seçilmesinin temel nedeni; yoğun bakım, cerrahi, dahiliye ve yenidoğan gibi farklı hasta gruplarına bakım verilen servislerde hemşirelerin iş yükünün ve hasta özelliklerinin farklı olması sebebiyle ebeveynlerin aile merkezli bakım felsefesine ilişkin görüşlerinin de farklı olabileceğinin düşünülmesidir Araştırmaya Türkçe konuşabilen, iletişim sorunu olmayan ve araştırmaya katılmayı kabul eden ebeveynler alınmıştır. Araştırmaya katılmayı reddeden ya da araştırma dışı bırakılan ebeveyn olmamıştır.

\section{Veri toplama aracı}

Veriler literatürden yararlanılarak geliştirilen ebeveyn veri toplama formu ile toplanmıştır $(12,22,24,27,28)$. Bu formda ebeveynlere ilişkin demografik bilgileri içeren 13 soru (yaşı, cinsiyeti, tanısı, hastaneye yatış şekli vb.), çocuğun hastalığına yönelik 7 soru (ebeveynin çocuğunun tanısını, tedavi protokolünü ve çocuğuna uygulanan girişimleri bilme durumu vb.) ve aile merkezli bakım uygulamalarını değerlendirmeyi amaçlayan 16 soru (ebeveynin çocuğunun bakım uygulamalarına katılma durumu, hemşire teslimlerine katılma durumları vb.) yer almaktadır. Veri toplama formunda 36 soru yer almaktadır. Veri toplama formunun ön uygulaması 10 ebeveyn ile yapılmış ve ön uygulama sonrası formda gerekli düzenlemeler yapılmıştır. Ebeveyn veri formu ebeveynlere, araştırmacılar tarafından yüz yüze görüşme yöntemi ile uygulanmış ve görüşme yaklaşık 45 dakika sürmüştür.

\section{Verilerin değerlendirilmesi}

Veriler IBM SPSS istatistik V 22 programında analiz edilmiştir. Verilerin analizinde ebeveynlerin tanımlayıcı bilgileri için sayı ve yüzde dağılımları, kategorik verilerin karşılaştırı ması için ise $x^{2}$ testi kullanılmıştır. Anlamlılık düzeyi $p<0.05$ olarak alınmıştır.

\section{Araştırmanın etik yönü}

Araştırmanın yapılabilmesi için araştırmanın yapıldığı üniversite hastanesinden yazılı izin ve ebeveynlerden yazııı onam alınmıştır. Ayrıca bu üniversitenin Girişimsel Olmayan Klinik Araştırmalar Etik Kurulu'ndan (etik kurul tarihi: 04.06.2014; sayı: GO14/276-21; karar numarası: 9) izin alınmıştır.

\section{Araştırmanın sınırlılıkları}

Araştırmamızın verileri araştırmaya katılan ebeveynlerin ifadelerinden oluşmaktadır. Ancak aile merkezli bakımın gerçekçi bir şekilde değerlendirilebilmesinde uygulamaların gözlenmesi daha etkili bir yaklaşım olarak önerilebilir. Ayrıca araştırmacılar tarafından literatürden yararlanılarak geliştirilen veri toplama formu ile aile merkezli bakımın en sık ifade edilen yönlerini değerlendirebilme şansı olmuştur. 


\section{Bulgular}

Araştırmamıza katılan ebeveynlerin \% 87.1'i annelerden oluşmakta ve yarısı (\%50.6) 30-40 yaş grubundadır. Ebeveynlerin \% 39.6'sı iki çocuğa sahip ve \%57.4'ü ilkokul ve ortaokul düzeyinde eğitim almış ve yaş ortalamaları 33.6'dır. Ebeveynlerin çocuklarının \%52.1'i erkek ve \%32.4'ü 2-5 yaş grubundadır. Çocukların \%78.2'si kronik hastalık tanısı ile izlenmekte, \%64.4'ü hastaneye planlı olarak yatış yapmış ve çoğunluğunun (\% 74.3) daha önce hastaneye yatış deneyimleri bulunmaktadır.

Araştırmamızda ebeveynlerin çoğu (\%95) hastanede çocuklarının bakımına katıldıklarını ifade etmişlerdir. Ebeveynlerin bakımda yaptığı uygulamalar incelendiğinde ise ilaç uygulaması ilk sırada (\%37.6), fizik tedavi hareketlerini uygulama ikinci sırada (\%10.6) yer almaktadır. Ebeveynlerin, çocukların bakımında yaptıkları diğer uygulamaların ise daha çok çocuğun temel fiziksel bakımını karşılamaya yönelik uygulamalar (örn: yemek yedirmek, hijyen gereksinimlerini karşılamak gibi) olduğu görülmektedir (Tablo 1).

Araştırmamızda ebeveynlerin \%60.1'i ( $n=182$ ) çocuklarına uygulanan tedavi protokolünü / kullandığı ilaçları ve $\% 60.1^{\prime} \mathrm{i}$ ( $n=182$ ) çocuklarına uygulanan girişimlerin (kan alma, idrar sondası takılması, enjeksiyon yapılması vb.) nedenlerini bilmediklerini belirtmişlerdir (Tablo 2).

Araştırmamıza katılan ebeveynlerin \%14.9'u hemşirelere soru soramadıklarını ifade etmişlerdir. Hemşirelere soru soramadıklarını ifade eden ebeveynlerin soru soramama nedenleri arasında en sık ifade ettikleri neden ise; hemşirelerin sorulara yanıt vermemeleridir. (\%10.2) (Tablo 2).

Ebeveynlerin eğitim düzeyine göre çocuklarının hastalığını bilme $\left(X^{2}=26.401 ; p<0.001\right)$, çocuklarının hastanede aldığı tedavi protokolünü/kullandığı ilaçları bilme $\left(X^{2}=37.188\right.$; $\mathrm{p}<0.001)$, hastanede çocuklarına uygulanan girişimlerin neden yapıldığını bilme durumları $\left(X^{2}=32.650 ; p<0.001\right)$ arasındaki fark istatistiksel olarak anlamlı bulunmuştur (Tablo 3 ).

Çocukların hastaneye yatış şekline göre ebeveynlerin hemşirelere soru sorabilme durumu incelendiğinde, çocukları hastaneye planlı yatış yapan ebeveynlerin hemşirelere daha fazla soru sordukları belirlenmiştir $\left(X^{2}=19.702\right.$; p<0.001) (Tablo 4).

Ebeveynlerin \%25.4'ü $(n=77)$ hemşire teslimlerine katılmadıklarını belirtmişlerdir (Tablo 5). Hemşire teslimlerine katılmadıklarını ifade eden ebeveynlere katılmama nedenleri sorulduğunda ise ifade ettikleri nedenler
Tablo 1. Ebeveynlerin çocuklarının bakımına katılma durumları ve

bakımda yaptıkları uygulamaların dağılımı

Ebeveynlerin Çocuklarının
Bakımına Katılma Durumla

Katılanlar

Katımayanlar

Sayı $\quad \%$

$288 \quad 95.0$

$15 \quad 5.0$

Ebeveynlerin Bakımda Yaptığı Uygulamalar

Tedavi Edici Uygulamalar (n:195ª)

illaç uygulama

Fizik tedavi hareketlerini uygulama

Pansuman yapma

Nazogastrik beslenme

Aspirasyon yapma

$114 \quad 37.6$

$32 \quad 10.6$

$20 \quad 6.6$

$16 \quad 5.3$

$13 \quad 4.3$

Diğer Uygulamalar (n:478)

Hijyen gereksinimlerini karşılama

Vücut Isısını ölçme

$240 \quad 79.2$

Giyinmeye yardımcı olma

59.7

abirden fazla seçenek işaretlenmiştir.

Tablo 2. Ebeveynlerin çocuklarının hastalığını, çocuklarına uygulanan tedavi protokolünü/kullandığı ilaçları, girişimlerin nedenlerini bilme ve çocuklarının bakımı ve tedavisi konusunda hemşirelere soru sorma durumları

\begin{tabular}{lcc} 
& Sayı & $\%$ \\
\hline $\begin{array}{l}\text { Ebeveynlerin Çocuklarının Hastalığını Bilme Durumu } \\
\text { Evet }\end{array}$ & 238 & 78.5 \\
Hayır & 65 & 21.5 \\
$\begin{array}{l}\text { Ebeveynlerin Çocuklarına Uygulanan Tedavi } \\
\text { Protokolünü /Kullandığı Illaçları Bilme Durumu }\end{array}$ & & \\
Evet & 121 & 39.9 \\
Hayır & 182 & 60.1 \\
$\begin{array}{l}\text { Ebeveynlerin Çocuklarına Uygulanan Girişimlerin } \\
\text { Nedenlerini Bilme Durumu }\end{array}$ & & \\
Evet & 121 & 39.9 \\
Hayır & 182 & 60.1 \\
Hemşirelere Soru Sorabilme Durumu & & \\
Evet & & \\
Bazen & 210 & 69.3 \\
Hayır & 48 & 15.8 \\
$\begin{array}{l}\text { Hemşirelere Soru Soramama Nedenleri (n:45) } \\
\text { Hemşirelerin sorulara yanıt vermemeleri }\end{array}$ & 45 & 14.9 \\
Hemşirelerin ebeveynlere olumsuz tutumları & 31 & \\
Ebeveynlerin soru sorma gereği duymamaları & 8 & 2.7 \\
& 6 & 2.0
\end{tabular}

sırasıyla; hemşirelerin teslimleri kendi aralarında yapmaları ve ebeveynleri teslimlere dahil etmemeleri $(n=35)$, ebeveynlerin teslimlere katılmaması gerektiğini düşünmeleri $(n=31)$ ve teslimleri anlamamalarıdır $(n=12)$. Araştırmada ebeveynlerin hemşire teslimlerine katılmayı isteme durumuna ilişkin görüşleri incelendiğinde, ebeveynlerin çoğunun (\%72.6) hemşire teslimlerine katılmayı istedikleri belirlenmiştir. 
Tablo 3. Ebeveynlerin eğitim düzeyine göre çocuklarının hastalığıı, çocuklarına uygulanan tedavi protokolünü/kullandığı ilaçları, girişimlerin nedenlerini bilme durumları

Ebeveynlerin Eğitim Düzeyi

\begin{tabular}{|c|c|c|c|c|c|c|c|c|c|c|c|c|c|c|c|c|}
\hline & & \multicolumn{2}{|c|}{$\begin{array}{c}\text { Okuryazar } \\
\text { değil }\end{array}$} & \multicolumn{2}{|c|}{ Okuryazar } & \multicolumn{2}{|c|}{ İlkokul } & \multicolumn{2}{|c|}{ Ortaokul } & \multicolumn{2}{|c|}{ Lise } & \multicolumn{2}{|c|}{ Üniversite } & \multicolumn{2}{|c|}{ Toplam } & \multirow[t]{2}{*}{$\begin{array}{l}X^{2} \\
p\end{array}$} \\
\hline & & $n$ & $\%$ & $n$ & $\%$ & $n$ & $\%$ & $n$ & $\%$ & $n$ & $\%$ & $n$ & $\%$ & $n$ & $\%$ & \\
\hline \multirow{2}{*}{$\begin{array}{l}\text { Ebeveynlerin çocuklarının } \\
\text { hastalığını bilme durumu }\end{array}$} & Evet & 4 & 1.3 & 0 & & 92 & 30.0 & 39 & 12.9 & 58 & 19.1 & 45 & 14.9 & 238 & 78.5 & \multirow{2}{*}{$\begin{array}{c}X 2=26.401 ; p< \\
0.001 \\
\text { df:5 }\end{array}$} \\
\hline & Hayır & 4 & 1.3 & 3 & 1.0 & 29 & 9.6 & 14 & 4.6 & 14 & 4.6 & 1 & 0.3 & 65 & 21.5 & \\
\hline \multirow{2}{*}{$\begin{array}{l}\text { Ebeveynin çocuklarına uygulanan } \\
\text { tedavi protokolünü /kullandığı } \\
\text { ilaçları bilme durumu }\end{array}$} & Evet & 0 & 0 & 1 & 0.3 & 35 & 11.6 & 18 & 5.9 & 34 & 11.2 & 33 & 10.9 & 121 & 40.0 & \multirow{2}{*}{$\begin{array}{c}X 2=37.188 \\
p<0.001 \\
d f: 10\end{array}$} \\
\hline & Hayır & 8 & 2.6 & 2 & 0.7 & 86 & 28.4 & 35 & 11.6 & 38 & 12.5 & 13 & 4.3 & 182 & 60.0 & \\
\hline \multirow{2}{*}{$\begin{array}{l}\text { Ebeveynin çocuklarına uygulanan } \\
\text { girişimlerin nedenlerini bilme } \\
\text { durumu }\end{array}$} & Evet & 0 & 0 & 1 & 0.3 & 35 & 11.6 & 18 & 5.9 & 34 & 11.2 & 33 & 10.9 & 121 & 40.0 & \multirow{2}{*}{$\begin{array}{c}X 2=32.650 \\
p<0.001 \\
\text { df:10 }\end{array}$} \\
\hline & Hayır & 8 & 2.6 & 2 & 0.7 & 86 & 28.4 & 35 & 11.6 & 38 & 12.5 & 13 & 4.3 & 182 & 60.0 & \\
\hline
\end{tabular}

Tablo 4. Çocukların hastaneye yatış şekline göre ebeveynlerin hemşirelere soru sorabilme durumları

\begin{tabular}{|c|c|c|c|c|c|c|c|c|}
\hline \multicolumn{9}{|c|}{ Hastaneye Yatış Şekli } \\
\hline & \multicolumn{2}{|c|}{ Acil } & \multicolumn{2}{|c|}{ Planlı } & \multicolumn{3}{|c|}{ Toplam } & \multirow{2}{*}{$\frac{X^{2}}{P}$} \\
\hline & & $n$ & $\%$ & $n$ & $\%$ & $\mathrm{n}$ & $\%$ & \\
\hline \multirow{3}{*}{$\begin{array}{l}\text { Ebeveynlerin } \\
\text { hemşirelere } \\
\text { soru sorabilme } \\
\text { durumları }\end{array}$} & Evet & 62 & 29.5 & 148 & 70.5 & 210 & 100 & $X 2=19.702$ \\
\hline & Bazen & 17 & 35.4 & 31 & 64.5 & 48 & 100 & $\begin{array}{c}\mathrm{p}<0.001 \\
\mathrm{df}: 2\end{array}$ \\
\hline & Hayır & 29 & 64.4 & 16 & 35.6 & 45 & 100 & \\
\hline
\end{tabular}

Ebeveynlere hemşire teslimlerini anlama durumları sorulduğunda ise, ebeveynlerin \%35,0'i hemşirelerin tıbbi terim kullanmaları nedeniyle teslimleri anlamadıklarını ifade etmişlerdir. Araştırmamızda ebeveynlerin eğitim düzeyine göre hemşire teslimlerini anlama durumları arasında istatistiksel olarak anlamlı bir fark bulunmuştur. Ebeveynlerin eğitim düzeyi arttıkça, hemşire teslimlerini anlama durumlarının arttığı belirlenmiştir $\left(X^{2}=27.546 ; p<0.002\right)$.

Araştırmamızda ebeveynlere teslimlere katılmanın avantajları ve dezavantajları da sorulmuştur. Ebeveynler teslime katılmanın kendileri için hastalık (\%59.1), ilaç (\%50.8) ve beslenme (\%55.2) gibi konularda bilgi sağlamak gibi avantajlarının olduğunu ifade etmişlerdir. Ayrıca ebeveynler hemşire teslimlerine katılmanın kafalarında karışıklık (\%44.9) ve anksiyete yaratmak (\%23.4'ü) gibi dezavantajları olduğunu belirtmişlerdir.

\section{Tartışma}

Aile merkezli bakımın temelinde, çocuğun sağlığı ve bakımını sürdürmede aile bütünlüğüne odaklanılmaSı, saygı, bilgi paylaşımı ve iş birliği bulunmaktadır (27). Ebeveynler cesaretlendirilerek çocuklarının günlük bakımına katılmaları sağlanarak ekibin bir parçası ve çocuklarının iyileşmesinde kısmen de olsa sorumluluk sahibi olduklarını hissedebilirler (28). Yapılan araştırmalar ebeveynlerin genellikle çocuklarının temel fiziksel bakımlarına katılmak istediklerini göstermektedir $(29,30)$. Çakmak ve Karaçam (2018) yaptıkları çalışmalarında araştırmamıza benzer olarak ebeveynlerin çoğunluğunun (\%95) çocuklarının bakımlarına aktif olarak katıldıklarını ve çocukların bakımında daha çok çocuğun temel fiziksel bakımını karşılamaya yönelik uygulamaları yaptıkları görülmüştür. Bunun nedeninin ailelerin daha çok evde yaptıklarına benzer aktiviteleri yapmak istemeleri ve çocuğa zarar vermekten korkmaları olduğu ifade edilebilir (14). Bunun yanında araştırmamızda ebeveynlerin bakım uygulamalarının yanında tedavi edici uygulamalara da katıldıkları görülmektedir. Literatüre baktığımızda da ebeveynlerin çocuklarının bakımında rol almak istediklerini ancak hemşirelik aktivitelerini yapmak istemedikleri ve kendilerinden beklenen rol ile ilgili karmaşa yaşadıklarını belirten araştırmalar olduğu belirlenmiştir $(10,29)$. Ebeveynler genellikle çocuklarının bakım gereksinimlerinin ihmal edilmediğinden emin olmak, hemşirelerle daha iyi iletişim kurmak ve çocuklarına daha iyi bir bakım sunulmasını sağlamak için istemedikleri halde çocukları ile ilgili çoğu aktiviteye katılmaktadırlar (30).

Yapılan bir araştırmada çocuğa yapılan ağrılı işlem sırasında ebeveynin bulunmasının hem ebeveynin hem de çocuğun anksiyetesini azalttığı belirlenmiştir (31). Bu nedenle de annelerin çoğunun ağrılı ve invaziv işlemlerde çocuklarının yanında kalmayı tercih ettikleri ve bu sayede çocuklarına tanıdık bir çevre ve duygusal destek sağlamayı amaçladıkları belirtilmektedir (12,32). Bizim araştırmamızda da ebeveynlerin çoğunluğunun $(\% 77,8)$ çocuklarına 
yönelik yapılan ağrılı işlemlerde çocuklarının yanında kalmak istediklerini belirtmişlerdir. Ayrıca araştırmamızda ebeveynlerin \%77,9'u ağrılı işlemler sırasında çocuklarının yanında kalabildikleri belirlenmiştir. Bu bulgu aile merkezli bakım uygulamaları açısından önemlidir. Çünkü sağlık çalışanları bu işlemlerde ebeveynlerin olmasını tercih etmemekte (33) ve ebeveynlerin ağıılı işlem deneyimleyen çocuklarını izlemesinin çocuk ve ebeveyn arasındaki bakım etkileşimini ve işlemin yapılmasını olumsuz etkileyebileceği konusunda endişelenmektedirler (34). Ayrıca araştırmamızda çocukların hastanede yatış süresi arttıkça, ebeveynlerin ağrılı işlemler sırasında çocukların yanında kalma durumlarının arttığı saptanmıştır. Bu durum hastanede kalış süresinin artmasıyla ebeveynlerin ortama alışmaları nedeniyle işleme katılmayı istediklerini gösterebilir.

Çocuğu hastanede yatan ebeveynler için hemşireler ve diğer sağlık personeli ile iletişim çocuğun bakımına katılmada ve olumlu bir hastaneye yatış deneyimi yaşayabilmelerinde en önemli faktörlerden biridir (10). Ebeveynlerin çoğu zaman sağlık personeline direkt olarak soru sorup istedikleri bilgiyi hemen alamamaları ve bilgi almak için beklemeleri iletişim sorununun artmasına neden olabilmektedir (10). Bununla birlikte hemşirelerin çocuğa yapılacak işlemler konusunda aileleri bilgilendirmeleri ebeveynlerin sağlık bakımına yönelik memnuniyet düzeylerinin artmasını da yol açabilmektedir (35). Ayrıca ebeveynler çocuklarına özel bakım aktivitelerini öğrenmek isteseler de hemşireleri sorularla rahatsız etmemeyi tercih etmekte ve rollerini genişletememektedirler (29). Araştırmamızda ebeveynlerin çoğunluğu $(\% 69,3)$ hemşirelere soru sorabildiklerini ancak \% 10,2'si hemşirelerin sorulara yanıt vermemeleri nedeniyle soru soramadıklarını belirtmişlerdir. Boztepe ve Çavuşoğlu'nun (36) yaptıkları araştırmalarında hemşirelerin çoğunlukla yoğun olmaları nedeniyle ebeveynlerin sorularına cevap veremedikleri ve bu nedenle ebeveynlerin soru sormaya çekindikleri belirlenmiştir. Tüm bu etkenler kliniklerde ebeveynler ve sağlık personeli arasındaki iletişim açığının giderek artmasına ve bu nedenle çoğu zaman iletişim problemlerine neden olabilmektedir.

Araştırmamızda çocukların hastaneye yatış şekli ve hemşirelere soru sorabilme durumu incelendiğinde hastaneye planlı yatış yapan çocukların ebeveynlerinin hemşirelere daha fazla soru sordukları belirlenmiştir. Bu durumun nedeni ebeveynlerin çocukları hastaneye planlı yatış yaptığında acil yatışlara göre daha az anksiyete yaşamaları ile açıklanabilir. Çünkü bir çocuk ani ve plansız bir şekilde hastaneye yatırıldığında özellikle de yoğun bakım ünitesine yatış durumlarında; ebeveynler stres, anksiyete ve rol karmaşası yaşayabilmektedirler (37). Bu nedenle plansız yatışı olan ebeveynlerin daha fazla desteklenmesi gerekebilir. Eğer ebeveynin soruları ve endişeleri varsa sağlık ekibinin özellikle de çocuk ve ebeveyn ile etkileşim içerisinde olan hemşirenin bu ebeveynlere hemşire teslimlerinde daha fazla zaman ayırması, onların endişe ve anksiyetelerini azaltmaya yardımcı olabilecektir.

Ebeveynlerle çocuğa ve hastalığına ilişkin bilgi paylaşımı aile merkezli bakımın temel taşlarından biridir. Bilgi paylaşımı olmadan aileler çocukları için karar verme sürecine katılamazlar ve bu nedenle sağlık çalışanları ile eşit bir ortaklık geliştiremezler (38). Mucuk ve Cimke (2017), annelere hastanede yatan çocuğa uygulanan bakım aktiviteleri hakkında bilgi verildiğinde sağlık bakımı ile ilgili memnuniyet düzeylerinin arttığını bildirmiştir (39). Ancak bu kadar önemli olmasına rağmen kliniklerde çoğu zaman ebeveynlerin bilgilendirilmesi yeterli oranda yapılamamaktadır. Araştırmamızda ebeveynlerin eğitim düzeyleri arttıkça ve ebeveynlerin çocuğunun hastalığını, çocuğunun hastanede aldığı tedavi protokolünü/ kullandığı ilaçları, hastanede çocuğuna uygulanan girişimlerin neden yapıldığını bilme durumları da artmaktadır. Bu durum eğitim düzeyi yüksek ebeveynlerin sağlık okuryazarlık düzeylerinin yüksek olmasından, kaynaklara daha kolay erişebilmelerinden ve bilgileri daha iyi anlamalarından kaynaklanabilir. Bu bulgu özellikle eğitim düzeyi düşük olan ebeveynler için farklı bilgilendirme ve eğitim tekniklerinin dikkate alınmasının ve ebeveynlerin bireysel özelliklerini dikkate alarak bakım verilmesi gerekliliğini göstermektedir.

Ebeveynlerin hemşire teslimlerine katılabilmeleri ebeveynlerle bilgi paylaşımında bulunabilmek için önemli bir fırsat olabilir (12). Çalışmamızda ebeveynlerin çoğunluğunun $(\% 72,6)$ teslimlere katılmayı tercih ettikleri ve ancak \%50,8'inin teslimlere katılabildikleri belirlenmiştir. Araştırmanın yapıldığı hastanede ailelerin teslime katılması ile ilgili herhangi bir protokol olmaksızın hemşirelerin teslimlerine aileleri dahil etmeleri, aile merkezli bakım uygulamaları açısından olumlu bir bulgudur. Çünkü ailenin teslimlere katılmasının hemşirelere engel oluşturabileceği düşüncesi aile merkezli bakımın uygulanmasındaki bariyerlerden biri olarak bildirilmiştir (40).

Araştırmamızda belirlenen ve ülkemizdeki literatürde ilk kez yer alan bulgu da ebeveynlerin eğitim düzeyi arttıkça, ebeveynlerin hemşire teslimlerini anlama durumlarının arttığı ve hastaneye planlı yatış yapan çocukların ebeveynlerinin hemşire teslimlerini daha çok dinlemesidir. Aile merkezli teslimler ile ebeveynler, bakıma daha fazla 
katıldıklarını, çocuklarının durumunu daha fazla anladıklarını, bakıma ilişkin memnuniyetlerinin arttığını ve bakım ekibine daha fazla güvendiklerini belirtmişlerdir $(24,25)$. Yapılan kalitatif tanımlayıcı bir araştırmada ise aile merkezli teslimlerin en değerli yönünün iletişim olduğu belirtilmiştir (23). Sonuç olarak sağlık personeli ve ebeveynler arasında güven ilişkisinin sağlanması, ebeveynlerin bakıma aktif bir şekilde katılımlarının sağlanması için ebeveynlerin hasta başı aile merkezli hemşirelik teslimlerine dâhil edilmesi oldukça büyük bir önem taşımaktadır.

\section{Sonuç}

Araştırmamızın Ankara'da sadece bir üniversitenin çocuk hastanesinde yapılmış olması bir sınırlılık olmakla birlikte; araştırmanın ebeveynlerin hemşire teslimlerine katılımları ile ilgili ülkemizde yapılan ilk ve büyük örnekleme sahip araştırma olması nedeniyle aile merkezli bakımla ilgili literatüre önemli katkılarda bulunduğu ifade edilebilir. Bulgular Türkiye'yi yansıtmadığı için daha kapsamlı ve tüm ülkeyi içeren araştırmaların yapılması önerilebilir.

\section{Kaynaklar}

1. Committee on Hospital Care and Institute for Patient- and Family-centered Care Patient- and Family-Centered Care and the Pediatrician's Role. Pediatrics 2012;129:394-404. [CrossRef]

2. Institute for Patient/Family Centered Care Core concepts of patient/ family centered care, 2010. Erişim adresi: http://www.ipfcc.org/ search.html?q=Core\%20Concepts Erişim tarihi:15.11.2014.

3. Gillis J, Rennick J. Affirming parental love in the pediatric intensive care unit. Pediatr Crit Care Med 2006;7:165-8. [CrossRef]

4. Roden J. The involvement of parents and nurses in the care of acutely-ill children in a non-specialist paediatric setting. J Child Health Care 2005;9:222-40. [CrossRef]

5. Lewandowski LA, Tesler MD. Society of Pediatric Nurses, \& American Nurses Association. Family-centered care: Putting it into action: The SPN/ANA guide to family-centered care. Washington DC: Amer Nurses Assn; 2003.

6. Frost M, Green A, Gance-Cleveland B, Kersten R, Irby C. Improving family-centered care through research. J Pediatr Nurs 2010;25:1447. [CrossRef]

7. Ames KE, Rennick JE, Baillargeon S. A qualitative interpretive study exploring parents'perception of the parental role in the paediatric intensive care unit. Intensive Crit Care Nurs 2011;27:143-50. [CrossRef]

8. Foster M, Whitehead F, Maybee P. Parents'and health professionals'perceptions of family centred care for children in hospital, in developed and developing countries: A review of the literature. Int J Nurs Stud 2010;47:1 184-93. [CrossRef]

9. Shelton TL, Stepanek JS. Family-centered care for children needing specialized health and developmental services. Washington, DC: Association for the Care of Children's Health; 1994. p.9.

10. Reid T, Bramwell R, Booth N, Weindling M. Perceptions of parent-staff communication in neonatal intensive care: the development of a rating scale. J Neonatal Nurs 2007;13:24-35. [CrossRef]
Araştırmanın yürütüldüğü hastanede istendik düzeyde olmasa da aile merkezli bakım uygulamalarının; ağrılı işlem ve bakıma katılma gibi yönlerinin gelişmekte olduğunu olumlu bir bulgu olarak belirtebiliriz. Ancak verilen bakımda ebeveynlerin eğitim düzeyi ya da çocuklarının hastaneye yatış şekli gibi özelliklerinin hemşireler tarafından yeterli düzeyde dikkate alınmadığını da görmekteyiz. Bu nedenle hastanede eğitim düzeyi ve hastaneye yatış şekli gibi ebeveynlerin aile merkezli bakım uygulamalarına katılımlarını etkileyecek özellikleri dikkate alarak bakımın planlanması yönünde politikalar geliştirilebilir. Ayrıca çalışmamızda ebeveynlerin hemşire teslimlerine katılmak istedikleri ve teslimleri anlayamamalarının onlar için bir engel olduğu belirlenmiştir. Bu nedenle aile merkezli bakım uygulamaları ile ilgili hastanelerde politika ve prosedürlerin geliştirilmesi önerilebilir.

\section{Teşekkür}

Yazarlar araştırmaya katılan ebeveynlere ve araştırmanın yapılmasına izin veren üniversite hastanesine teşekkür etmektedirler.

11. Wigert $H$, Johansson $R$, Berg M, Hellstrom AL. Mothers'experiences of having their newborn child in a neonatal intensive care unit. Scand J Caring Sci 2006;20:35-41. [CrossRef]

12. Şener DK, Karaca A. Mutual Expectations of Mothers of Hospitalized Children and Pediatric Nurses Who Provided Care: Qualitative Study. J Pediatr Nurs 2017;34:e22-8. [CrossRef]

13. Tosun A, Güdücü Tüfekci F. Çocuk Kliniklerinde Aile Merkezli Bakım Uygulamalarının İncelenmesi. J Anat Nurs Health Sci 2015;18:1319. Erişim: http://e-dergi.atauni.edu.tr/ataunihem/article/ view/1025009912/5000117323

14. ÇakmakE, Karaçam Z. The correlation between mothers'participation in infant care in the NICU and their anxiety and problem-solving skill levels in caregiving. J Matern Fetal Neonatal Med 2018;31:21-31. [CrossRef]

15. Aykanat B, Gözen D. Çocuk sağlığı hemşireliğinde aile merkezli bakım yaklaşımı. GÜSD 2014;3:683-95. Erişim: http://dergipark. ulakbim.gov.tr/gumussagbil/article/view/5000003531/5000004045

16. Boerner KE, Chambers CT, McGrath PJ, LoLordo V, Uher, R. The Effect of Parental Modeling on Child Pain Responses: The Role of Parent and Child Sex. J Pain 2017;18:702-15. [CrossRef]

17. Özcetin M, Suren M, Karaaslan E, Colak E, Kaya S, Guner O. Effects of parent's presence on pain tolerance in children during venipuncture: A randomised controlled trial. HK J Pediatr (New Series) 2011;16:24752. Erişim: http://www.hkjpaed.org/details.asp?id=805\&show=1234

18. Hielkema M, Winter AF, Reijneveld SA. Validity of a family-centered approach for assessing infants'social-emotional wellbeing and their developmental context: a prospective cohort study. BMC Pediatr 2017;17:148.

19. Reijneveld SA, Hielkema M, Stewart RE, de Winter AF. The added value of a family-centered approach to optimize infants'socialemotional development: A quasi-experimental study. PloS ONE 2017;12:e0187750. [CrossRef]

20. Çamur Z. Hastanede yatan çocuğun bakımına ebeveyn katılımının ebeveyn memnuniyetine, ebeveyn ve çocuk anksiyetesine etkisi (Master's thesis) 2017. 
21. Committee on Hospital Care. American Academy of Pediatrics. Family-centered care and the pediatrician's role. Pediatrics 2003;112:691-6. [CrossRef]

22. Sisterhen LL, Blaszak RT, Woods MB, Smith CE. Defining familycentered rounds. Teach Learn Med 2007;19:319-22. [CrossRef]

23. Latta LC, Dick R, Parry C, Tamura GS. Parental responses to involvement in rounds on a pediatric inpatient unit at a teaching hospital: A qualitative study. Acad Med 2008;83:292-7. [CrossRef]

24. Rosen P, Stenger E, Bochkoris M, Hannon MJ, Kwoh CK. Familycentered multidisciplinary rounds enhance the team approach in pediatrics. Pediatrics 2009;123:e603-8. [CrossRef]

25. Aronson $P$, Yau J, Helfaer M, Morrison W. Impact of family presence during pediatric intensive care unit rounds on the family and medical team. Pediatrics 2009;124:1119-25. [CrossRef]

26. Gonzalo JD, Chuang $\mathrm{CH}$, Huang $\mathrm{G}$, Smith $\mathrm{C}$. The return of bedside rounds: an educational intervention. J Gen Intern Med 2010;25:7928. [CrossRef]

27. Johnson B, Abraham M, Conway J, Simmons L, Edgman-Levitan S Sodomka P, et al. Partnering with patients and families to design a patient- and family-centered health care system: Recommendations and promising practices 2008. Institute for Family-Centered Care. Bethesda, Maryland: Institute for Family-Centered Care and the Institute for Healthcare Improvement; April 2008.

28. Turley KM, Higgins SS. When parents participate in critical pathway management following pediatric cardiovascular surgery. MCN Am J Matern Child Nurs 1996;21:229-34. [CrossRef]

29. Blower K, Morgan K. Great expectations? Parental participation in care. J Child Health Care 2000;4:60-5. [CrossRef]

30. Coyne I, Cowley S. Challenging the philosophy of partnership with parents: a grounded theory study. Int J Nurs Stud 2007;44:893-904. [CrossRef]
31. Cavender K, Goff MD, Hollon EC, Guzzetta CE. Parents'Positioning and Distracting Children During Venipuncture Effects on Children's Pain, Fear, and Distress. J Holist Nurs 2004;22:32-56. [CrossRef]

32. Boie ET, Moore GP, Brummett C, Nelson DR. Do parents want to be present during invasive procedures performed on their children in the emergency department? A survey of 400 parents. Ann Emerg Med 1999;34:70-4. [CrossRef]

33. Boztepe H. Pediatric nurse views regarding parental presence during a child's painful procedures. Ağri 2012:171-9. [CrossRef]

34. Walker W. Accident and emergency staff opinion on the effects of family presence during adult resuscitation: critical literature review. J Adv Nurs 2007;61:348-62. [CrossRef]

35. Arıkan D, Saban F, Gürarslan Baş N. Çocuğu hastanede yatan ebeveynlerin hastaneye ve sağlık bakımına yönelik memnuniyet düzeyleri. İzmir Dr. Behçet Uz Çocuk Hast Derg 2014;4:109-16. [CrossRef]

36. Boztepe H. Çavuşoğlu H. Examination of a family centered care practice at the children's units of a university hospital. J Hacettepe Univ Nurs Fac 2009;11-24.

37. Noyes, J. The impact of knowing your child is critically ill. A qualitative study of mothers'experiences. J Adv Nurs 1999;29:427-35. [CrossRef]

38. Butler A, Copnell B, Willetts G. Family-centred care in the paediatric intensive care unit: an integrative review of the literature. J Clin Nurs 2014;23:2086-2100. [CrossRef]

39. Mucuk S, Cimke S. Mothers'Participation in the Hospitalized Children's Care and their Satisfaction. Int J Caring Sci 2001;10:1643. Erişim: http://www.internationaljournalofcaringsciences.org/ docs/59_2_cimke_original_10_3.pdf

40. Boztepe H, Kerimoğlu Yıldız G. Nurses perceptions of barriers to implementing family-centered care in a pediatric setting: A qualitative study. J Spec Pediatr Nurs 2017;22. [CrossRef] 